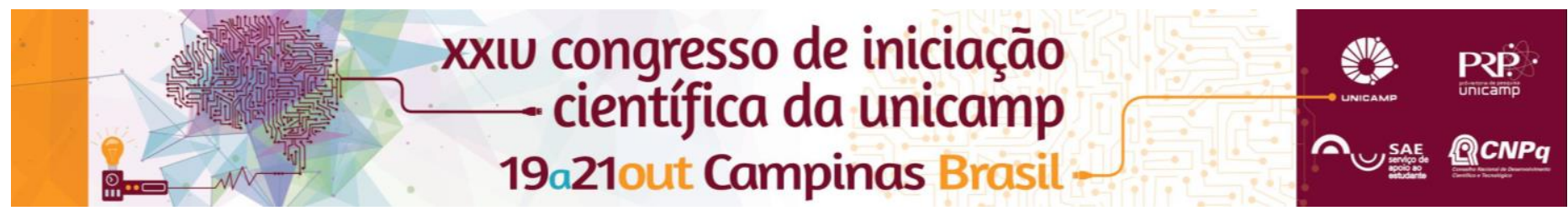

\title{
Amiloidose sistêmica primária- Diagnóstico Histopatológico e Características Clínicas- Relato de Três Casos
}

\author{
Angélica Y. M. Uno*, Regina Maria I. Ruscalleda
}

\section{Resumo}

A amiloidose compreende um grupo de doenças heterogêneas, as quais possuem em comum a deposição extracelular de fibrilas proteicas insolúveis em órgãos e tecidos. Os autores relatam três casos de amiloidose sistêmica primária que cursaram com rápida evolução a óbito.

\section{Palavras-chave: \\ Amiloide, amiloidose, amiloidose sistêmica}

\section{Introdução}

Amiloide representou termo utilizado por Virchow em 1854 para caracterizar substância semelhante ao amido constatada na macr oscopia de órgãos ${ }^{1}$. Amiloidose consiste em distúrbio proteico que resulta na deposição de amiloide em tecidos e órgãos. À microscopia visualiza-se substância eosinofílica e hialina, que se cora com vermelho congo e apresenta birrefringência verdeesmeralda à luz polarizada ${ }^{2}$. É constituído por cadeias polipeptídicas dispostas em lâminas $\beta$ pregueadas entre $\mathrm{si}^{3}$. Classifica-se em localizada e sistêmica. Esta apresenta-se como: 1. primária, com depósitos de fragmentos de cadeia leve de imunoglobulinas monoclonais; 2. secundária a processos inflamatórios e infecciosos ${ }^{2}$, como, artrite reumatoide, hanseníase; 3. hereditária. Amiloidose sistêmica pode ocasionar óbito em $20 \%$ dos portadores em cerca de seis meses após o diagnóstico ${ }^{4}$. Em classificação internacional recente ${ }^{5} 31$ fibrilas amiloides foram descritas. A partir do quadro clínico e da presença de amiloide no tecido ou órgão é possível estimar qual a forma clínica mais provável.

Em estudo retrospectivo não finalizado de portadores de amiloidose atendidos em Hospital Universitário (HU), os autores relatam três casos de amiloidose primária que cursaram com rápida evolução a óbito.

\section{Relato de Casos}

CASO I. Sexo feminino, 53 anos. Buscou atendimento médico referindo edema de membros inferiores (MMII) há um ano, edema de face, oligúria e aumento de peso. Exames laboratoriais (EL): cadeias $\mathrm{k}-139 \mathrm{mg} / \mathrm{dL}$ e $\lambda-169$ $\mathrm{mg} / \mathrm{dL}$, proteína de Bence Jones (BJ) negativo; proteinúria$5,24 \mathrm{~g} / 24 \mathrm{~h}$, Biópsia (BP) renal-amiloidose; BP de medula óssea-hiperplasia celular e conglomerados linfoides. Internou-se dez meses após para transplante de medula óssea autólogo e diagnósticos de amiloidose renal de cadeia $\lambda$ e Síndrome Nefrótica. Evoluiu com derrame pleural bilateral, insuficiência renal aguda, acidose metabólica, choque e óbito após dez dias de internação e um ano e dez meses após início dos sintomas.

CASO II. Sexo feminino, 65 anos. Encaminhada ao ambulatório de Nefrologia em com história de edema em MMII há 4 meses e urina I com proteinúria de 2,4 g/l. Exame físico (EF): edema frio em MMII 4+/4+ até a coxa. EL: aumento de cadeias $\lambda$. BP renal realizada sete meses após 0 primeiro atendimento demonstrou depósitos de amiloide. Com o diagnóstico de amiloidose de cadeia leve foi submetida a tratamento quimioterápico com cinco ciclos de melfalan e prednisona. Sem melhora dos sintomas, optou-se por quimioterapia com vincristina e doxorrubicina endovenosos. Após o segundo ciclo apresentou dispneia e aumento do edema em MMII. EF: acianótica 1+/4+, dispneica, taquicárdica (120bpm), edema 3+/4+ em MMII, cianose e livedo reticular. Evoluiu com hipotensão arterial persistente e bradicardia não responsiva às manobras de ressuscitação, seguida de óbito um ano e cinco meses após primeiro atendimento.

CASO III. Sexo feminino, 75 anos. Buscou atendimento médico em HU referindo edema em MMIl e aumento do volume abdominal e prurido há um ano. Relatou amiloidose ganglionar há dois anos, sem acompanhamento médico. EF: BEG, descorada 2+/4+ ictérica 2+/4+, abdômen globoso, hepatomegalia, ascite e circulação colateral. EL: proteinúria de $0,23 \mathrm{~g} / 24 \mathrm{~h}$, BJ positiva; BP hepática- extenso infiltrado amiloide, $\mathrm{K} / \lambda$ 2,42 . BP de medula óssea-hiperplasia celular. Com diagnóstico de mieloma múltiplo (MM) IIA iniciou-se tratamento com melfalan e prednisona. Após três ciclos evoluiu a óbito seis meses após o atendimento no HU.

\section{Conclusões}

Apesar dos avanços quanto à classificação e amiloidose pode associar-se a condição clínica de maior gravidade, como as formas primárias. Nos relatos apresentados as três pacientes eram mulheres, com idades acima de 50 anos. Houve evolução a óbito entre 1 ano e cinco meses e dois anos após início dos sintomas. Destacam-se para o diagnóstico a importância dos sintomas, particularmente a presença de edema generalizado, exames complementares, diagnósticos diferenciais, entre eles as diversas causas de proteinúria e síndrome nefrótica, a indicação de biópsia do órgão mais comprometido. Nas formas primárias destacam-se a pesquisa de cadeias leves e a biópsia de medula óssea. Ressalta a importância do diagnóstico precoce para que todos os recursos terapêuticos possam ser utilizados, entre eles quimioterapia e transplante de medula.

\footnotetext{
1 COHEN, A.S.; SIPE, J. D. Review: History of Amyloidosis, Journal of Structural Biology, Boston, v.130, p. 88-98, 2000.

2- PEPYS, M.B. Amyloidosis, Revista Medicina, Londres, v.57, 2006

3- HUSBY, G.; et al. Serum amyloid A (SAA): biochemistry, genetics and the pathogenesis of AA amyloidosis. Disponível em:

[https://www.researchgate.net/publication/232089919_Serum_amyloid_A_\%2 8SAA\%29_Biochemistry_genetics_and_the_pathogenesis_of_AAamyloidosis] Acesso em 10 de Março de 2016

4- ASÚA, D. A.; et al. Systemic amyloidosis AA: epidemiology, diagnosis and management. Disponível em:

[http://www.ncbi.nlm.nih.gov/pmc/articles/PMC4218891/]. Acesso em $10 \mathrm{de}$ Março de 2016

5. SIPE, J. D.; et al. Nomenclature 2014: Amyloid fibril proteins and clinical classification of the amyloidosis. Amyloid, 2014; 21(4): 221-224. Acesso em 10 de Março de 2016.
} 